\title{
مقترح لإعادة هيكلة التعليم العالي التقي في اليمن
}

\section{Proposal to re-think the higher technical education system in Yemen}

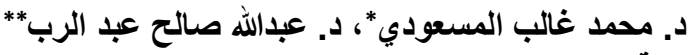

$$
\begin{aligned}
& \text { كلية المجتمع، عدن، اليمن. } \\
& \text { البريد الإلكتروني: masoudi.ye@gmail.com }
\end{aligned}
$$

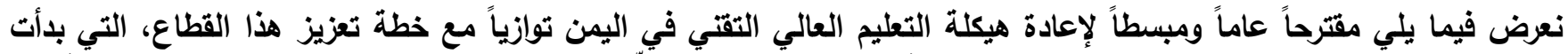

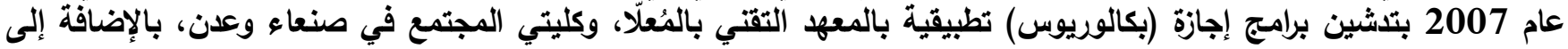

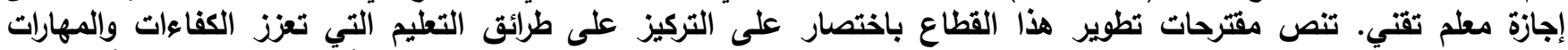

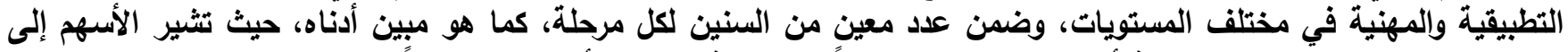

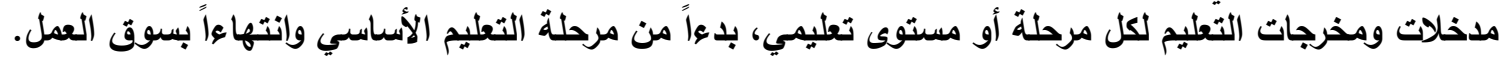

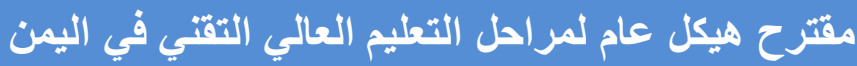

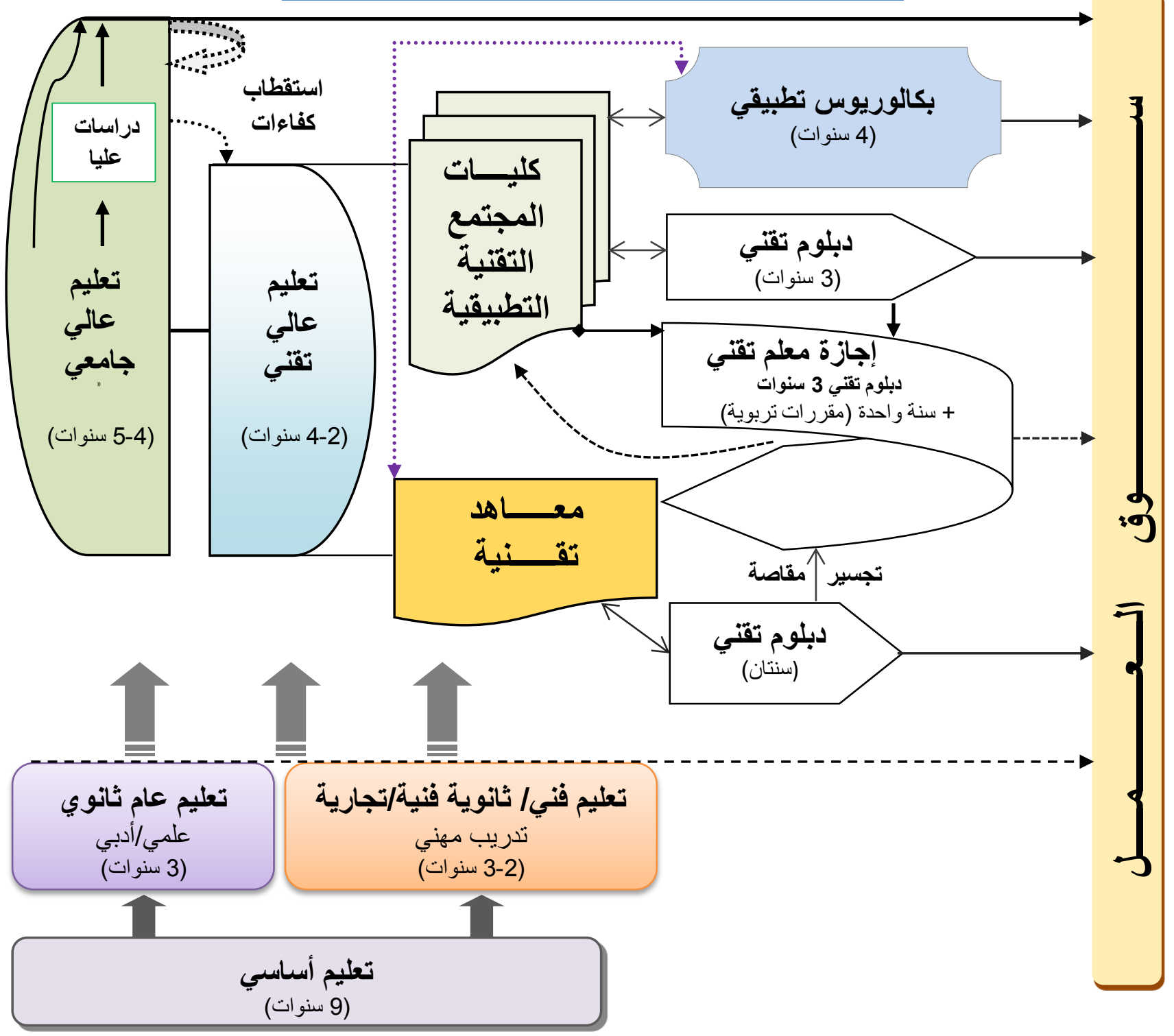

